\title{
THE ENFORCEMENT OF COLLECTIVE LABOR AGREEMENTS: A PROPOSAL
}

\author{
HARRY D. WOLF*
}

The past few years have witnessed an unprecedented growth in trade-union membership in this country. Equally impressive are the victories which organized labor has won during the same period. Accompanying these conquests there has been a sharp increase in the number and magnitude of industrial disputes.

That favorable legislation, particularly the National Labor Relations Act, has contributed largely to labor's successes is accepted by every one. The same source is credited by many as also being responsible for the increased number of strikes and lockouts. Both the National Labor Relations Act and its administration have become the objects of wide-spread criticism, especially from the employer side. The Act has been denounced as a fomenter of industrial strife and as placing the employer in an unfair position in dealing with his employees. A flood of proposals has been forthcoming, some of which, embodied in bills, have already been introduced in Congress. If enacted into law they would amend the Act in various respects, curtail the powers of the National Labor Relations Board, require the incorporation or registration of unions, etc.

With much of this criticism, and with the corresponding remedies offered, we are not immediately concerned. Directly pertinent to our topic, however, is a renewal of the demand, as old perhaps as the unions' claim for recognition and collective bargaining, that labor be compelled to accept responsibilities commensurate with its increased powers and privileges. The National Association of Manufacturers, for example, demands that the National Labor Relations Act and similar state acts be so amended that no employer may be penalized for failure to deal with any labor organization guilty of organizing, supporting, or maintaining strikes in violation of employment agreements, including agreements to accept an arbitration award. ${ }^{1}$ The Association also demands "legal and social responsibility of both employer and employee for their commitments and their acts," and declares that "unincorporated employer associations and labor organizations should be sueable, and should have

- B,S., 1922, Kansas State Teachers College (Emporia); M.A., x923, Ph.D., 1926, University of Chicago. Professor of Economics, University of North Carolina, teaching courses in labor problems and industrial relations. Author: The Railroad Labor Board (University of Chicago Press, 1927).

${ }^{2}$ National Association of Manufacturers, pamphlet, Industry's Platform for 1938 (1937).

For a discussion of these demands, see Gall and Smethurst, Amending the Wagner Act: The Problem from the Manufacturer's Viewpoint, infra, p. 306. ED. 
the right to maintain suits in their own names, as entities, in all jurisdictions." "Little Business," in its recent statement to the President, also asked that ". . . employer and employee alike be held responsible for the faithful observance of mutual labor agreements."2

This raises at once the question whether or not collective bargaining agreements should be made legally enforceable by statutory enactment. An affirmative answer would raise the further question of machinery and procedure for carrying out a policy of enforcement. Should they be made enforceable through the courts as ordinary contracts, or is it desirable that specialized machinery be established for that purpose? It may assist us in answering these questions if we first inquire into the present legal status of the collective bargaining agreement in the United States and elsewhere.

In contrast to nearly every other industrialized country, the legal status of the collective bargaining agreement in the United States has never been defined by statutory enactment. In those countries where compulsory arbitration prevails, for example, Australia and New Zealand, agreements voluntarily entered into are usually given the same status as an arbitration award and made legally binding. In practically all of the European countries agreements have been made enforceable by legislative decree. In England the agreements of the Trade and Agricultural Boards, although not always the outcome of genuine collective bargaining, are legally enforceable, but those of the National Whitley Councils are not. ${ }^{3}$ Under the Cotton Manufacturing Act of 1934 England adopted the principle of extending voluntary agreements to third parties not signatories thereto and not involved in the negotiations, where more than a majority of the organized employers and organized employees enter into an agreement. 4 So far this practice applies only to the cottonweaving industry in the Lancashire district. The same principle has been applied to the textile industry in a number of other countries. It has been adopted most widely in Canada where four of the provinces have made it applicable to one or more industries. Where it is in use the agreements are legally binding and individual contracts establishing less favorable terms for the employees are illegal.

The suggestion that collective bargaining agreements be made enforceable through statutory enactment may give the false impression that agreements are not legally enforceable at present: While it is true that their legal status has not been defined by statute in the United States, as we have just seen, the same is true of many other phases of union activity. And, as in the case of these other açtivities, it is the decisions of the courts to which we must turn to find the law as it applies to the collective bargaining agreement. A brief examination of the findings of the courts will reveal that certain rights and obligations accrue to the several parties under the agreement, while others appear to be in the process of evolution.

The United States News, Feb. 7, 1938.

'Sells, The Settlement of Industrial Disputes in Great Britain, infra, at p. 321.

"Legalization of Collective Agreements in Foreign Countries (1936) 43 U.S. MontruY Lasor RzV. 398. 
The earlier position taken by the courts was that collective bargaining agreements were in the nature of gentlemen's agreements, enforceable, if at all, only through the sense of moral responsibility of the parties thereto, and the power of each to bring pressure on the other. The attitude then prevailing was well expressed by Professor Commons." "A contract with a trade union is not a contract in law," he declared, "it is merely an understanding, or a usage, or a joint agreement, that when the real labor contract is made between individual employer and employee, it will be made according to the terms of the joint agreement. If an individual employer breaks the agreement by hiring a workman on different terms, the only means that the union has of enforcing the agreement is that of a strike ... the employer's only practicable remedy is the lockout ... as it now stands a joint trade agreement is a kind of usage or understanding agreed to by two opposing interests and generally enforced on individuals by the coercive weapons of strike, lockout, boycott, or blacklist."

As implied here, despite the tenuous nature of the agreement itself, the individual employee was early recognized as acquiring rights under it under certain conditions. A detailed consideration of the several theories which the courts have followed in relating the individual contract to the collective agreement is not essential to our purposes, and would take us too far afield. ${ }^{6}$ It must be noted, however, that in order to avail himself of his rights under the agreement, the individual employee must be held to have come under its terms. On this point some courts have ruled that before an employee can recover for a breach of the agreement he must have affirmatively "ratified" or "adopted" the agreement. Others have held that an acceptance or continuance of employment with knowledge of the terms of the agreement is suffcient to establish such rights. Still others have taken the position that where a collective bargaining agreement exists all workers more or less automatically come under its terms. Where this latter view prevails even non-union employees have secured redress in accordance with the terms of the agreement.

The chief concern of the individual employee is with such matters as wages, seniority rights, and discharge. Where violations of provisions relating to these vital issues have come before the courts, how have they ruled?

The courts appear to have acted with greater uniformity on the question of wages than on any other single issue. Employees found to have an interest under an agreement, including non-union employees, have recovered the difference when paid less than the agreement called for. Even here, however, exceptions are to be found. Where employees have been discharged contrary to the provisions of the agreement

${ }^{5}$ U. S. Comm'n on Industrial Relations, Final. Report and Testimonx, Sen. Doc. 4i5, 64 th Cong., Ist Sess. (1915) vol. I, p. I92.

- The writer has made no attempt to examine all of the many cases involving agreements which have been handed down by the courts. In preparing this summary of the law as it now stands, he has depended largely upon the articles here listed. He, of course, assumes full responsibility for any errors of fact or emphasis. Fuchs, Collective Labor Agreements in American Law (1925) ro ST. Lous L. Rev. I; Rice, Collective Labor Agreements in American Law (193I) 44 HaRv. L. Rev. 572; Christenson, Legally Enforcing Interests in American Labor Union Working Agreements (1933) 9 IND. L. J. 69; Anderson, Collective Bargaining Agreements (1936) I5 ORE. L. Rev. 229; Note (1931) 31 CoL. L. Rev. II56; Note (1938) 51 Harv. L. REv. 520. 
they have, in many cases, been reinstated, not infrequently with pay for time lost. In other cases factors such as lack of mutuality have resulted in refusal to grant specific performance or damages or other equitable relief. The situation is still less certain with respect to seniority rights. A study of forty-two cases in which seniority was the principal issue revealed that relief was granted in only six. ${ }^{\top}$ Relief was denied in the remainder of the cases because of refusal to compel specific performance, no breach of agreement, defective pleading, etc. The findings in this study led to the observation that "while no circumstance has been uncovered in which an American Court has specifically stated that seniority clauses cannot legally be enforced, neither have there been many situations in which the relief asked for has been granted."8

In recent years there has been an increasing tendency on the part of the courts to recognize an interest on the part of the union in the collective agreement, in addition to that which accrues to the individual members. There is a considerable lack of uniformity here, however, arising, for the most part, out of questions of juristic personality and mutuality of consideration. Some courts recognize unincorporated unions as entities, capable of suing and being sued, as such. Others hold that in the absence of an enabling statute, an unincorporated union can neither sue nor be sued. Most courts are able to find sufficient consideration in the collective bargaining agreement to give it the standing of a contract. Others, even in recent cases, do not.

Where agreements are recognized as enforceable, the damage suit, although not unknown, has been used but little. Although specific performance is sometimes refused, equity is ordinarily relied upon to hold the parties to the agreement through injunction. Since Schlesinger v. Quinto, ${ }^{9}$ the first case of outstanding importance in which a union secured an injunction to compel employer observance of an agreement, organized labor has made increasing use of this means of enforcement. ${ }^{10}$ Specific acts in violation of an agreement such as lockouts, general wage reductions, violations of closed shop provisions, discharge of union men and replacement by non-union, are among those which have been successfully enjoined.

Despite the protestations of organized labor that legal enforceability of agreements would mean enforcement against the union but not against the employer, ${ }^{11}$ the experience in the courts seems to prove the reverse the more nearly true. The obstacles to the successful prosecution of the damage suit against the union or its members have rendered it a relatively unimportant means of enforcement. Here again, refusal on the part of the courts to compel specific performance has limited, but by no means eliminated, the use of the injunction. Strikes in violation of an agreement as well as the various activities essential to the conduct of strikes, such as the issuance of the strike call, picketing, the use of strike funds, etc, have been restrained by this means.

"Christenson, Seniority Rights utzder Labor Union Working Agreements (1937) II TEMpLE L. Q. 355.

${ }^{8} 1 d$. at 378 .

'II7 Misc. 735, 192 N. Y. Supp. 564 (r922), aff'd, 201 App. Div., 487, 194 N. Y. Supp. 401 (1922).

${ }^{10}$ Witte, Labor's Resort to Injunctions (1930) 39 YALE L. J. 374.

" Gildean, Metzods of Industrial Peace (Ig04) I6r. 
More than twenty years ago Professor Robert Hoxie characterized the law as it then applied to organized labor as being uncertain, among other things, and as lacking in uniformity. ${ }^{12}$ It is evident from the foregoing discussion that his characterization is still applicable, so far as collective bargaining agreements are concerned. The difficulty is not so much that such agreements are altogether legally unenforceable, but rather that there is often so much uncertainty as to their legal status within the jurisdiction of a given court, and so little uniformity as between the jurisdictions of the several courts, that the resulting situation is satisfactory to no one.

Assuming the desirability of legal certainty and uniformity on this phase of labor relations, as on others, we may ask, to what extent could they be achieved through statutory enactment? A further and even more important consideration would be the probable effect of such a policy on collective bargaining. Would it have the desired effect of tending to promote it, or would it be a force working in the opposite direction? The proposal will bear further consideration with the collective bargaining process in mind, especially as it has been affected by recent legislation.

The primary requisite to the collective bargaining process is the free exercise of the employee's right to belong and to participate in the activities of a labor organization of his own choice. While there are other factors which help to explain the relatively small degree of unionization in the United States in the past, and even at present, the force of employer opposition must be regarded as one of the most important. There can be no doubt that in safeguarding the exercise of this right such measures as the Norris-La Guardia Act and the National Labor Relations Act, together with the corresponding state legislation, have contributed both to simple justice and to the promotion of genuine collective bargaining.

With respect to the employer's obligation to bargain collectively, as is required both by the National Labor Relations Act and the several state labor relations acts, the case is not so clear. ${ }^{13}$ That the government has the power to bring the two parties together for the purpose of bargaining is evident. But that it has the further power to bring about the mental attitudes necessary to reach an agreement has been questioned. ${ }^{14}$ If it be granted that simply bringing employers and employees face to face across the conference table is a necessary first step toward reaching an agreement, the question then arises as to whether or not such an obligation on the employer is a mild form of unilateral compulsory arbitration. ${ }^{15}$ While a consideration of such points is beyond the scope of this paper, the requirements which give rise to them

\footnotetext{
2 Hoxie, Trade Unionism in the United States (igig) 218.

1 Five states, Massachusetts, New York, Pennsylvania, Utah, and Wisconsin passed laws, patterned after the federal act, in 1937 .

"Spencer, Collective Bargaining Under Section $7(a)$ of the National. Industrial Recovery Act (I935) 5 Univ. of Chicago, Studies in Business Administration, No. 3, p. 30.

${ }^{15}$ Id. at 31.
} 
should be kept in mind, it would seem, in attempting to decide on the advisability of making collective bargaining agreements legally enforceable.

A further question which presents itself is whether or not, if the government, having legally obligated the employer to bargain, were then to make agreements legally enforceable, it would be attempting to do for organized labor something that the latter should do for itself. Certainly such a program runs counter to the position which organized labor in this country has taken in the past. Given free exercise of their right to organize and freedom from such handicaps as the injunction, the unions have insisted that they could compel the employer, through their economic strength, to recognize them and to bargain collectively.

The demand for legal enforceability of agreements in the past has usually been expressed in the demand that unions be compelled to incorporate. For many years incorporation has been and is at present vigorously opposed by organized labor. However, the arguments that have been advanced against enforceability can be separated, in most cases, from those against incorporation. Underlying all else, perhaps, has been the fear that any step in the direction of governmental control over industrial relations would be the entering wedge which might eventually result in compulsory arbitration and limitation on the right to strike.

One reason why organized labor has opposed making agreements legally enforceable has been because of the fear, as indicated above, that they would be enforced against the union but not against the employer. Expressing skepticism that "the facts which constitute a practical violation of a contract could be presented as legal evidence in the court," Mr. Gompers declared that "the grievances from which the organized workers suffer are not in its specific violation, but by the surreptitious efforts, by indirect means, to overcome the terms of a contract and practically annul it."16 Granting that Mr. Gomper's fears may not have been wholly groundless, subsequent experience with agreements in the courts seems to indicate that on the whole the unions have not fared so badly.

Even before, but especially since the Coronado case, ${ }^{17}$ organized labor, in reply to demands that they accept greater responsibility, have maintained that additional responsibility was unnecessary. Furthermore, it has been consistently denied that making agreements legally enforceable would make them any more binding than they already were; that such action would remove the sense of moral responsibility and would tend to increase rather than decrease the likelihood of violation. As one of the most beloved labor leaders that this country has known, John Mitchell, stated it: "There is such a thing as a moral as well as a legal responsibility, and in many cases the word of a man or an organization will bind him, when, if it were a legal agreement, he might hire a lawyer to drive a coach and four through it."18 In addition to the statement of moral responsibility, the implication here, of course, is that

\footnotetext{
${ }^{16}$ Quoted in Gilman, op. cit. supra note Ir, at $\mathrm{I} 6 \mathrm{r}$.

${ }^{27}$ United Mine Workers v. Coronado Coal Co., 259 U. S. 344 (1922), holding a union sueable under the. Sherman Act.

${ }^{18}$ Mitchell, Organized Lasor (rg03) 224.
} 
in making agreements legally enforceable, a premium would be placed on the drawing of the document with an eye to possible future loopholes, which would have a tendency toward endless litigation.

Aside from or, perhaps better, in addition to a recognition of the moral obligations imposed on them by the agreement, union leaders have been fully aware that the employer's willingness to deal with the union, and consequently the effectiveness, if not the existence, of the union itself depended upon the extent to which it lived up to its obligations. The succinct warning recently attributed to a prominent labor official perhaps sums up the attitude which responsible union leaders have held toward collective bargain-agreements: "Observe your contract and your union grows. Violate it and your union dies."19

This is not to say that violations of agreements, both by employers and unions, are unknown, or even uncommon. Just how extensive violations are, in fact, is impossible to determine because of lack of data, conflicting testimony, disagreement as to what constitutes a violation, etc. The preponderance of the evidence, however, seems to indicate that agreements, on the whole, are well kept and that violations are the exception. ${ }^{20}$ Examples are not lacking of agreements that have been in successful operation for nearly half a century. The United Mine Workers are claimed to have agreements which have run for more than fifty years. ${ }^{21}$ The agreement in the stove branch of the molding industry was established in I8gr and has been successfully renewed from time to time since. ${ }^{22}$ Reviewing the experience of his organization with collective bargaining, the president of the Glass Bottle Blowers' Association in 1920 declared that in more than thirty-five years neither side had ever violated the agreement, nor had it ever been necessary to call in an outsider to help 0 adjust differences which had arisen. ${ }^{23}$ Similar examples of successful operation can be found in other lines, particularly the needle trades, the printing trades, and the railroads.

The more common charge of violation, however, is not that either employers or unions deliberately and flagrantly repudiate the agreement. To cite Mr. Gompers again, the employer is accused of evading and practically annulling the agreement, which constitutes a violation of the spirit if not the letter. Against such subtle manipulations the employees feel that they have no recourse except to strike, and are thus made to appear in the eyes of the public as being the violators themselves. Similarly, union officials are charged not with openly repudiating and authorizing violations, but with failing to take sufficiently vigorous steps to keep their membership in line, and perhaps with condoning or even secretly encouraging unauthorized

${ }^{17}$ Statement by Phillip Murray, quoted in Time, Dec. 27, 1937.

${ }^{20}$ U. S. Comm'N ON Indestrial Rezations, op. cit. supra note 5, at ig2; see also McCabe, National Collective Bargaining in the Pottery Industry (1932) 349; Blochł Labor Agreements in Coni Mines (I93I) 319.

${ }^{2}$ Statement by David Saposs in Metcalf, Collective Bargaining for Today and Tomorrow (1937) 31 .

${ }_{22}$ Bouder, National Collective Bargaining in the Foundry Industry (1934) 24 Ax. EcoN. REv. 462.

${ }^{23}$ Quoted in (193I) I5 International Labour Rev. I99. 
strikes. The attitude of employers toward the union's failure to control its membership is well expressed in the following statement made last year when the flood of stoppages and unauthorized strikes was at its height: "Unless trade union officials can exercise sufficient control over the members of their unions to prevent them from indulging in unauthorized sit-downs from time to time, employers will naturally find it futile to enter into collective bargaining agreements."24

That violations of this type occur, and in considerable number, there is no doubt. Although both the number and the consequences are probably sometimes exaggerated for public consumption, the literature is replete with examples. Nor has any completely satisfactory way of preventing them yet been found. As indicated above, responsible union leaders have deplored them, and have usually taken prompt steps to settle them when they have occurred. Many union constitutions contain prohibitions against unauthorized strikes, and not infrequently both individuals and local bodies have been punished by fine or expulsion. ${ }^{25}$

The foregoing discussion may be considered as a statement of the case, in part, against taking further action to make collective bargaining agreements legally enforceable. As a final point, it seems pertinent to ask what effect, if any, the large number of unauthorized strikes which occurred last year has had on the progress of collective bargaining, and on the readiness of employers to renew old agreements or enter into new ones. If the current situation can be taken as indicative, they seem to have had little effect in this direction. To the best of the writer's knowledge no agreement of any consequence terminating recently has failed of renewal. On the other hand, there has been a flood of new ones entered into, including some of outstanding importance. Despite the recession in general business conditions, the number of agreements has increased steadily. ${ }^{26}$

While the writer recognizes that a pretty substantial case might be built up against attempting to make collective bargaining agreements any more legally enforceable than they now are, he is of the belief that the case for doing so is the more convincing, taking into consideration conditions and circumstances as they now exist. In the first place, the intent of the parties at the time of making the agreement must be to abide by it, otherwise the whole process of collective bargaining becomes futile. And there is evidence that certain unions endeavor to draw their agreements in such a way that they will be legally enforceable. ${ }^{27}$ In the second place, it is a fact that breaches of agreements do occur and that they have a disruptive effect. Any proposal that might tend to reduce their number must be given serious consideration. Furthermore, legal enforceability would remove the argument of union irresponsibility, however specious it may be, which, on occasion, is offered as an excuse for refusing to recognize and bargain collectively with organized labor.

$\approx$ I I NAt. INd. Conf. Bd., BulletiN, No. 6, May 4, 1927, p. 50.

$25 \mathrm{Bloch}$, op. cit. supra note 20, at 309; McCABE, op. cit. sispra note 20, at 3 ro; Clark, Collective Bargaining in the United States of America (1927) I5 INTERNATIONaL LaBour Rev. 211.

${ }^{28}$ See New York Times, March 6, 1938.

${ }^{7}$ Chrustenson, Collective Bargaining in Chicago: 1929-30 (1933) 326. 
It has been seen too that the unions themselves have been turning more and more in recent years to the courts to enforce agreements, with the result that the courts have already gone far in rendering them legally enforceable. The uncertainty and lack of uniformity which prevail as a consequence could undoubtedly be largely reduced by legislative enactment. Moreover, the successful enforcement of agreements requires intimate acquaintance with the detailed and specific subject matter with which the agreement deals, and which, in the nature of things, the courts cannot always be expected to have. Legislative enactment would make possible the establishment of machinery and procedure of enforcement more adapted to the needs. Finally, to require collective bargaining without requiring the resulting agreement to be observed appears to be putting the cart before the horse. Since it seems unlikely that the employer's legal obligation to bargain could be removed, even if it were considered desirable, it seems logical to take the next step and make the agreement legally enforceable. With the foregoing in mind, the following proposal for making collective bargaining agreements legally enforceable by legislative enactment is submitted.

III

It should be clearly understood that the proposal offered here applies only to agreements after they have once been made. There is no suggestion that there should be any element of compulsion on the parties to enter into the agreement in the first place. Not only to remove any doubt on this point but to facilitate the procedure outlined below, it seems desirable to give legal status only to those agreements which, having been voluntarily entered into, are registered with the proper administrative agency at the mutual request of the parties. ${ }^{28}$ Furthermore, the suggestion contemplates the continuance of the present legislation bearing on the collective bargaining process which is provided under the National Labor Relations Act and the several corresponding state acts.

The question may be raised at the outset of the willingness of the two parties to register an agreement and thus subject themselves to the provisions of such legislation. In reply it could be said that a refusal on the part of either party to register an agreement might reasonably be looked upon as a lack of good faith. Presumably little difficulty would be encountered from the employer side, since it is they who are demanding stricter observance of agreements. But might not a union consider that it might possibly have more to lose than to gain by submitting to registration? Such an objection might be met, it would seem, by a demand on the part of the employer for registration as a condition of entering into an agreement. It could be provided that an employer making such a demand and having satisfied the requirements of the National Labor Relations Act in other respects, would be within his rights if he refused to enter into an agreement unless it were registered.

\footnotetext{
* Various proposals have been made for the voluntary registration and enforcement of agreements, e.g., see recommendations of the Special Comamtee, Twentietf Century Fund, Labor and Government (1935) 363 et seq.; Slichter, The Government and Collective Bargaining (I935) 178 ANwazs, I07; H. R. 2737, 75th Cong., Ist Sess. (1937).
} 
While the selection of effective machinery and procedure for implementing the legal enforceability of agreements is one that calls for careful consideration, it would seem to offer no insuperable difficulties. In fact, all of the necessary elements of both machinery and procedure are to be found in operation in this country at the present time, and could be adapted to the needs of such a proposal as is suggested here with but little difficulty.

The first step in making collective bargaining agreements legally enforceable would be to declare that a violation of the agreement, or of any of its terms, by either party thereto would constitute an unfair labor practice. This could be done by simply adding a paragraph to that effect to Section 8 of the National Labor Relations Act. ${ }^{20}$ A violation, or a threatened violation would then set the machinery of enforcement in operation upon appeal by either party.

Such machinery might well consist of, first, a federal agency comparable to the National Labor Relations Board. Unless the additional duties arising out of the enforceability of agreements would place too great a burden on an already overworked and under-staffed body, there is much to be said for making the Board itself the superstructure of the machinery here contemplated. ${ }^{30}$ While a distinction can and should be made between the collective bargaining process which culminates rather than terminates in the agreement, and the enforcement of the agreement itself, the two are so closely related that it would seem both logical and expedient for the same agency to administer both. But whether this were done, or a separate agency established, the functions would be the same. For convenience in exposition, let us suppose the National Labor Relations Board be given these duties. Such duties would be, first, to receive agreements for registration, with power of refusal if in the judgment of the Board they were contrary to the public interest; ${ }^{31}$ and second, to follow the prescribed procedure outlined below to prevent violation of a registered agreement where such might be threatened, and to compel restitution to be made, if deemed advisable, where violation had already occurred.

Thus far no reference has been made to the part the states are expected to take under this proposal. To avoid questions of constitutionality, as well as to expedite the prompt handling of complaints, machinery and procedure comparable to that suggested here for the federal government should be established in each of the several states. Such a suggestion would merely project a little further the parallel provisions now found in the National Labor Relations Act and the state labor relations acts. Wisconsin has already gone a long way in this direction by making provision in its Labor Relations Act for hearing by the Wisconsin Labor Relations Board of complaints alleging breach of agreement. After hearing, unless the difficulty

\footnotetext{
20 The Special Committee of the Twentieth Century Fund recommended the addition of such a provision to the Wagner-Connery bill, in its report op. cit. supra note 28 , at 384 . See also Slichter, op. cit. supra note 28 , at 116 .

${ }^{\circ}$ It may be anticipated that the current burden upon the Board will greatly decline as employer resistance to union recognition and collective bargaining is overcome.

${ }^{31}$ Certain affirmative requirements might be prescribed as conditions to registration, as, for example, that adequate provision be made in each agreement for the adjustment of grievances in the first instance.
} 
is adjusted, the Board may make public its findings. It may also refer its findings for "appropriate action" to the employers committee provided for in the Act, if any employer is the violator, or to the labor committee in case of a breach by a labor organization. ${ }^{32}$ For the sake of convenience the following discussion, while confined to the proposal as it involves the federal government, will be understood to be equally applicable to the states.

To facilitate the handling of charges of violation, and to place the maximum degree of responsibility on the parties themselves in carrying out their agreements, some such distinction should be made between violations as is now made between disputes under the Railway Labor Act. ${ }^{33}$ Recognizing two general categories of disputes, first, those concerning rates of pay, rules, or working conditions; ${ }^{34}$ and second, those growing out of grievances or out of the interpretation of agreements concerning rates of pay, rules, or working conditions, ${ }^{35}$ the Act establishes a different procedure in the case of each. A similar distinction should be made with respect to violations. In case of a major violation, or an impending major violation, where, for example, one side threatened to repudiate the agreement, or refused to follow the procedure prescribed therein for negotiating a new agreement, ${ }^{36}$ appeal might be made by the other side directly to the National Labor Relations Board, as may now be done under the Board's regulations with complaints of unfair practices where quick disposition is required. The procedure from this point on would be the same as it now follows in complaint cases. That is, the Board might hear the case itself, or it might designate a trial examiner to take evidence. Should the Board find the party named in the complaint guilty of an unfair labor practice, i.e., of violating or having violated a registered agreement, it would issue an order requiring such party to cease and desist from such unfair labor practice. To make its orders effective the Board would, as now, petition any circuit court of appeals for the enforcement of its order.

Violations of lesser magnitude would ordinarily arise from grievances, or from disputes concerning the interpretation or application of the agreement. The machinery and procedure established under the Railway Labor Act, modified to meet the needs of a particular bargaining unit, might well be taken as a model for the proposal under consideration.

The Railway Labor $\mathrm{Act}^{37}$ provides that in case a dispute arises ". . out of grievances or out of the interpretation or application of agreements concerning rates of pay, rules, or working conditions ....," it shall be handled "in the usual manner up to and including the chief operating officer of the carrier designated to handie such dispute." Upon failure of adjustment, it may be referred by petition of the parties, or by either party, to the appropriate division of the Adjustment Board. The Adjustment Board is a permanent bipartisan board of thirty-six members, represent-

\footnotetext{
Wis. Laws 1937 , c. III, par. III.0I(4). $\quad{ }^{33} 45^{\circ}$ U. S. C., c. 8 (1936).

sId. $\$ 5$.

$\approx$ Id. $\$ \$ 2,3$.

${ }^{30}$ It will be noted that at this point the enforcement process and the bargaining process overlap.

${ }^{5} 45$ U. S. C. $\$ 3$.
} 
ing equally the carriers and the employees, and consists of four divisions, each having jurisdiction over certain classes of employees. Each division has power to hear disputes referred to it by either party coming within its jurisdiction and by majority vote, to make an award which is final and binding, except insofar as it contains a money award. In case of deadlock or failure to secure a majority vote, the division is required to select a neutral party known as a referee to sit with the division and to make an award. If the division fails to agree upon a referee such person is appointed by the National Mediation Board.

To fit this plan into the proposal under consideration, ${ }^{38}$ the award of the Adjustment Board, while final and binding on the parties, would be referred to the National Labor Relations Board to compel observance should either party prove recalcitrant. The Board, on finding that the proper procedure had been followed, and that the dispute was within the jurisdiction of the Adjustment Board, would accept the latter's award and issue an order making it effective.

The basic requirements for this aspect of the writer's proposal are that machinery for the handling of grievances and minor disputes be provided in all registered agreements and that this include provision for the rendition, in cases not settled more promptly, of awards by an arbitral body. Provided these requirements were met, uniformity would not be essential; the plans could be adjusted to the special needs of the bargaining parties. Indeed, the writer knows of no other industry with quite as elaborate a set-up as is to be found on the railroads. While there are some, for example, in the men's clothing markets which do not fall far short, it is not believed that such elaborate machinery would be necessary in most cases. The machinery and procedure usually found in present-day agreements would probably be adequate for the purpose here, or could be made so with little difficulty. The series of steps contemplated would run somewhat as follows, varying somewhat with the type of machinery provided and the size of the bargaining unit. First, an alleged violation would be taken up between the individual worker and the foreman. If not adjusted, the shop committee might confer with the foreman and superintendent of the department involved, and if no agreement were reached, with the general manager of the plant, with perhaps outside representatives of the union and higher officials of the company as the next step. The final resort would be to submit the matter to an arbitration. ${ }^{39}$ If the bargaining unit were a large one permanent machinery resembling a division of the Railroad Adjustment Board might be desirable. In smaller bargaining units, temporary boards, such as agreements now commonly provide, would probably serve the purpose. In either case, the award should be final and binding, with access to the National Labor Relations Board for enforcement, if necessary.

\footnotetext{
${ }^{3}$ The procedure under the Railway Labor Act is cited merely as illustrative; there is no suggestion that the railroads and their employees should come under the plan proposed herein.

50 The procedure outlined here is essentially that provided in the agreement between the CarnegieIllinois Steel Corporation and the Steel Workers Organizing Committec. See (1937) 44 U. S. MoNruLY LABOR REV. I92.
} 
The value of the procedure here outlined lies in placing the primary responsibility of adjusting differences and fulfilling obligations on the parties themselves. At the same time it utilizes machinery which is either at hand or can be easily established, and which is essential to a prompt disposition of complaints of violation. It would parallel, in large part, the practice established under the Railway Labor Act for which one of the chief advantages claimed is the increasing tendency toward the local settlement of disputes. ${ }^{40}$

\section{IV}

To what extent can the probable effectiveness of the proposal for legal enforceability set forth here be estimated? That it would be highly effective as it would apply to the employer is indicated by the experience under the National Labor Relations Act. Employers have been successfully enjoined from continuing those activities designated as unfair labor practices; and have been required to make proper restitution such as restoring employees to their proper positions where seniority rights have been violated, and taking back workers with pay for lost time where wrongful discharge has occurred. In short, such activities as are now declared to be unfair labor practices, so far as the employer is concerned, are in large part precisely the ones that would be expected to arise if collective bargaining agreements were made legally enforceable. Considered from the administrative viewpoint there would seem little doubt that the determination of violation of agreement would be a simpler matter than judging whether or not an employer is bargaining in good faith.

Such a plan would probably be equally effective so far as the union itself is concerned. Most agreements now forbid either strike or lockout, at least until after all provisions for reaching a settlement have been complied with. Both strikes and lockouts in violation of an agreement would be designated as unfair labor practices, and offenders would be subject to cease and desist orders from the Board. Since the most likely violation on the part of the union would be a strike contrary to the terms of the agreement, the strike itself and all of the activities essential to the conduct of the strike, such as picketing, the use of strike funds, etc., could be enjoined. Despite the fact that the Norris-La Guardia Act does not differentiate between disputes growing out of violation of agreements and other disputes, the view has been expressed that "both employers and employees may still obtain injunctions to prevent breaches of collective bargaining agreements between them."11 In the New York law, to cite the same authority, "this appears to have been reserved by the provision that injunctions might still be issued to prevent breaches of a contract not contrary to public policy." ${ }^{2}$ In any event, an act along the lines of this proposal would supersede the earlier law insofar as the two conflicted.

Control over the individual worker would seem to offer no particular difficulties. Normally his range of violations would extend over only a small area. His employ-

\footnotetext{
${ }^{0}$ Nationaz Mediation Bonrd, Third Annual Report (i937) 6.

"Frankel, Recent Statutes Affecting Labor Injunctions and Yellow Dog Contracts (1936) 30 IrL. L. Rkv. 854, 872. But see Note (1938) 5I Harv. L. Rev. 520, 53 I.

${ }^{2}$ Frankel, supra note $4 \mathrm{I}$, at $873 \mathrm{n}$.
} 
ment is ordinarily terminable at will, and in any case he has the right to cease work at any time he sees fit. He has practically no specific obligations under an agreement other than those which accrue to him as a member of the union. In those cases where his activities might properly be considered as violations of an agreement, for example, the soliciting of union membership on company property or on company time, both of which are sometimes forbidden by the agreement, the power of the employer to discharge, and of the union to take appropriate disciplinary, action, would be sufficient to keep him in line.

It may be observed here that majority rule, as is provided for under the Railway Labor Act, the National Labor Relations Act, and the several state labor relations acts would assist in making union control over individuals and minority groups more effective. As a corollary, the individual worker should not have the right to make individual contracts less favorable to himself than the agreement calls for. The provisions of both the National Labor Relations Act and the corresponding state acts permitting the closed shop where-it is desired by the majority, or at least the preferential shop, would, when availed of, make control by the employer and the union more effective, but would be by no means absolutely essential.

The problem which would seem to offer the greatest difficulty in making collective bargaining agreements legally enforceable as here proposed would arise in connection with the unauthorized strike. If the number engaging in such a strike were small, as is sometimes the case, the same pressure that could be brought to bear on the individual violator would probably be sufficient. As is not infrequently the case, however, the number engaging in such a strike may be quite large. In such a situation the employer's right of discharge loses much of its effectiveness. Since such strikes are also not infrequently in defiance of union orders, the union's control likewise loses much of its effectiveness. Unless the strike were deliberately planned, with strike benefits, picketing, and all the activities usually attendant upon a strike, the assistance that could be expected from the Board would be practically nil. In a situation like this what should be the responsibility of the union?

It goes without saying, of course, that the union should take such disciplinary action as it has within its power, such as fine or expulsion. Likewise, it should cooperate with the management in filling the places vacated by the unauthorized strikers and in restoring production. But should union responsibility go beyond this? Concretely, should the union be made liable through the damage suit?

There is something to be said for making the union financially responsible. Unauthorized strikes and stoppages inflict losses upon the employer, and it is the hope, in part, of freedom from such stoppages and losses that persuades him to enter into an agreement. Furthermore, the argument that if the union is going to assume the responsibility of acting as the bargaining agency for the employees, it must also accept the responsibility for disciplining its membership and keeping it in line is not without force.

On the other hand, to place financial responsibility for the acts of all individuals 
who may claim membership in a union-and the closed union has few defenderswould be to place it in an impossible situation. It is true that unauthorized strikes may, upon occasion, be directed as much against corrupt or inept union officials as against the employer. But it is also true that they may also be the work of chronic dissentionists and destructionists. To make unions legally liable, i.e., subject to damage suits for unauthorized breaches of agreements would be to weaken and render them ineffective, and undo much that has been done toward the promotion of collective bargaining.

Nor does the writer believe that the problem of unauthorized strikes and stoppages is as serious as it may seem. Without outside support, no relatively small group can either hope for a very large measure of success, nor hold out for long, unless the conditions are very unusual. And where the union discourages and takes prompt steps against them as the evidence shows is the rule and not the exception, unauthorized stoppage and "outlaw" strikes are generally short-lived. Moreover, even with groups of considerable size the employer's power of discharge is far from being unimportant. When backed by the union, with its power to fine and even expel-no light punishment where benefits accrued over a period of years may be jeopardized-it becomes exceedingly drastic.

Finally, it may be observed that stoppage and unauthorized strikes are of relatively little importance where the union is well established and where collective bargaining has been practiced over a considerable period of time. It is in the newly organized industries and areas, where organization has been prohibited, and sometimes with a heavy hand, that we see them at their worst. To develop discipline among the rank and file, to instill respect for orderly processes, and to build up a tradition of living up to agreements require time and patience. The successful experience with collective bargaining and observance of agreements exemplified in many lines of industry in this country is a tribute to industrial statesmanship on both sides, and to mutual confidence and respect. The writer believes that a policy which would clarify and make certain the legal status of agreements, and which gives promise of closer observance by both parties, would tend to promote these qualities so essential to successful collective bargaining. 